\title{
The Effect of Inductive and Deductive Teaching on EFL Undergraduates' Achievement in Grammar at the Hashemite University in Jordan
}

\author{
Mohammad M. Obeidat ${ }^{1} \&$ Moh'd A. Alomari ${ }^{2}$ \\ ${ }^{1}$ Faculty of Educational Sciences, The Hashemite University, Jordan \\ ${ }^{2}$ Faculty of Arts, The Hashemite University, Jordan \\ Correspondence: Mohammed M. Obeidat, Faculty of Educational Sciences, The Hashemite University, P.O Box \\ 330127, Zarqa 13133, Jordan
}

Received: February 10, 2020

Accepted: February 24, 2020

Online Published: February 25, 2020

doi:10.5430/ijhe.v9n2p280

URL: https://doi.org/10.5430/ijhe.v9n2p280

\begin{abstract}
This current study aims at investigating the impact of using inductive and deductive teaching upon EFL undergraduate students' achievement at the Hashemite University. More specifically, the study attempts to explore the effect of using inductive and deductive approach on students' achievement in some grammatical issues included a book adopted for teaching Grammar 2 in the Department of English Language and Literature. The research instrument used is a pre-post-test developed by the researchers. Two groups of students are chosen for the purpose of the study. Whereas the experimental group was taught through inductive approach, the controlled group was taught through the deductive approach. Results show significant differences between the means of students' scores in the two groups on the post-test, in favor of the experimental group. Results also reveal no significant differences according to study-year, the type of school they graduated from, and gender. In light of these results, the researchers suggest some recommendations for TEFL researchers and EFL instructors.
\end{abstract}

Keywords: inductive teaching, deductive teaching, EFL undergraduates, achievement, Hashemite University

\section{Introduction}

\subsection{Deductive and Inductive Teaching}

The deductive and inductive methods of teaching are very distinct and they oppose each other in many aspects. The most important difference between these two methods lies in the role of the teacher. In a deductive classroom, the teacher gives lessons by introducing and explaining concepts to students, who are expected then to complete exercises or tasks to practice these concepts. This means that the deductive method is a teacher-centered approach. In an inductive classroom, however, the teacher makes use of a strategy known as "noticing". That is, learners are given the chance to derive the rule from the examples provided to them. It is hypothesized that learners need to notice a concept, a structure, or a rule so that they can hold it in their short- or long-term memory (Bilash, 2009: 1). Moreover, research argues that the main difference between these two methods is the direction of the flow of information. Whereas the direction of the flow of information in inductive teaching is from specific to general, the direction in deductive teaching is from general to specific (Decision tree, 2012).

English grammar is not easy to learn for both native and non-native speakers. There are so many obscure rules and exceptions that make it difficult for the learners to understand this aspect of language. Teachers have used various approaches to teaching grammar so that the learners can better absorb these rules and exceptions better and can use them efficiently in real-life situations. Two of these approaches are associated with deductive and inductive teaching. The deductive approach emphasizes instruction before practice. A teacher gives students detailed explanations of a grammatical rule before they encounter the same rule in their own writing. After the lesson, students are expected to practice what they have been shown or presented in an automatic way, through exercises and worksheets. On the other hand, the inductive approach involves presenting examples that clarify a specific rule and expecting students to notice the way in which the rule works from these examples. This approach allows for easier retention of the rule than if the students were given an explanation that was disconnected from examples of the rule (Macfadyen, 2015).

Research argues that the deductive approach is the most traditional in grammar teaching. The teacher through this approach explains the rule, usually in the first language (L1), and then asks the students to practice some examples. The disadvantage of this approach is that the rule is easy to forget, and it is easy for the students to lose focus since 
the activity is not engaging and the rules have not been practiced in real-life examples. As for the inductive approach, the rules are normally discovered and not directly explained. Instead, students learn the rules through examples and testing them out. This approach has two main advantages: (1) It keeps the student's brain active as $\mathrm{s} / \mathrm{he}$ tries to figure out how grammar works. (2) It gives the teacher the chance to notice students' questions and to correct errors when appropriate. The disadvantage of this approach, however, is that it takes more time to prepare for, and it takes up more class time (Donalo, Beyerlein, \& Fiero, 2017).

The inductive and deductive approaches to teaching English as a second or foreign language (TESOL) are common in the teaching-learning context. The inductive approach is a sort of discovery learning that focuses on the learner. For example, an instructor might show examples of a grammar point in English and then ask students about what they notice. This encourages the student to participate, to rely on his or her critical thinking to figure out the language, and to gain deeper understanding of the language. On the other hand, the deductive approach is a more teacher-centered approach where the grammar point is explicitly introduced and explained and then tested. This allows the instructor to spend time in the classroom only on the language principle and to encourage faster learning of material (International Teacher Training Organization, 2019).

\subsection{Problem of the Study}

Many studies were done on the effectiveness of deductive and inductive approaches to teaching English as a foreign language (EFL) at the school level. A few of these studies were carried out at the university level. They focused on the impact of these two approaches on oral proficiency, language accuracy or grammar performance, and communication. Therefore, the present study attempts to fill this gap in the national, regional and international literature and to shed light on the extent to which each approach has an effect on EFL undergraduate students' achievement.

\subsection{The Purpose and Questions of the Study}

The purpose of this study is to investigate the impact of inductive and deductive approaches in teaching grammar upon EFL undergraduates' achievement at the Hashemite University. More specifically, the study attempts to explore the effect of using inductive and deductive methods of teaching on students' achievement in some grammatical issues included in the book adopted for teaching Grammar 2 in the Department of English Language and Literature. Overall, the study attempts to answer the following questions:

1. Are there any statistically significant differences $(\alpha=0.05)$ between the means of students' achievement in grammar according to teaching approach (inductive and deductive)?

2. Are there any statistically significant differences $(\alpha=0.05)$ between the means of students' achievement in grammar according to study-year (first and second year)?

3. Are there any statistically significant differences $(\alpha=0.05)$ between the means of students' achievement in grammar according to the type of school they graduated from?

4. Are there any statistically significant differences $(\alpha=0.05)$ between the means of students' achievement in grammar according to gender (males and females)?

\section{Review of the Related Studies}

Many studies were done on the effectiveness of inductive and deductive approach in teaching EFL in general and grammar in particular. Some of these studies emphasize that the inductive approach to teaching is more effective than the deductive one. In a study conducted by Gorat and Prijambodo (2013), who investigated the effect of using deductive and inductive approach in teaching English to 64 students (32 in each section) on their conditional sentence mastery, it was found that inductive teaching approach was more effective than deductive teaching approach. In the study carried out by Eriksson (2014), who examined the effectiveness of modified inductive learning of English grammar among foreign language students, it was also found that the inductive method was more effective than the deductive. The study executed by Alzu'bi (2015), who explored the effectiveness of teaching English grammar by using deductive and inductive teaching models with 80 university students and 100 elementary school ones in Jordan, showed that there were statistical significant differences among the grammar performance means of both groups at both levels in favor of inductive method. The exploration done by Kaur and Niwas (2016) on 70 university students ( 35 in each section) with regard to the effectiveness of inductive and deductive methods in teaching English grammar, revealed that teaching through inductive method had a significant impact upon student achievement. Similar results were obtained by Benitez-Correa, Gonzalez-Torres, Ochoa-Cueva and Vargas-Saritama (2019), who examined the effectiveness of the two approaches on the achievement of seventy students enrolled in the 
second year of senior high school. The results of the test indicated a significant difference in the scores, in favor of the inductive approach.

Some of the studies conducted in the international literature showed that inductive and deductive EFL teaching were equal in their effectiveness. For example, Ana and Ratminingsih's (2012) investigation of introducing an innovative strategy, which combined deductive and inductive approach for teaching English tenses for adult learners, showed that EFL teachers should not merely teach their learners to be able to remember the grammatical rules of English, but more importantly they also have to guide the learners to understand those rules and make them able to use those rules communicatively. Mahjoob's (2015) exploration of the effectiveness of inductive and deductive methods of grammar teaching on $60 \mathrm{EFL}$ students (30 in each group) studying in a language institute in the university of Shiraz, revealed that although there were differences in the mean grade point average of both groups, no statistically significant difference was observed between their achievement. Emre's thesis (2015), which examined the effects of inductive grammar instruction and deductive grammar instruction on 38 students' (19 each group)) acquisition of conditionals and relative clauses, indicated no statistically significant differences between the pre- and post-test scores of the two groups. Hejvani and Farahani's (2018) comparison of the efficiency of inductive and deductive methods in teaching English grammar by inspecting students' performance showed that both the inductive and deductive methods were equal in terms of efficiency. Ahmedzai, Katawazai and SC's (2019) investigation of the effectiveness of using these two approaches in teaching grammar to 218 Afghan students revealed no significant difference of using one approach over another and students could learn through both deductive and inductive approaches.

A few studies conducted in this regard indicated that the deductive approach to teaching grammar is more effective than the inductive. For example, Mohammed and Jaber (2008), who investigated the effects of deductive and inductive approaches in teaching the active and passive voice sentences on ninety-three freshmen and junior university students, found a statistical significant difference between the two approaches, in favor of the deductive. Sik (2015), who explored the effectiveness of inductive and deductive methods in teaching grammar to adult learners in terms of effectiveness on academic success, found that when the academic success of the students was considered, deductive teaching of grammar is slightly more effective than inductive teaching although this difference was not significant according to statistical data. They also showed that lecturers felt better when they taught grammar deductively. Negahdaripour and Amirghassemi (2016), who examined whether or not deductive and deductive instruction would differently affect EFL learners' accuracy and fluency, found that a deductive approach towards grammar instruction could have a more positive impact on EFL learners' oral accuracy.

However, many approaches to teaching EFL are suggested in the international literature. Some of them are traditional approaches and others are contemporary ones. Theorists and practitioners have not yet found the best method which best suits the students' level of achievement. Therefore, the present study has come to the scene to complement those done at the university level. It tries to find which approach to teaching is more effective in students' achievement in the Jordanian context, taking the Hashemite University students as a case study.

\section{Methods}

A quantitative case study approach was employed in this study. The aim was to investigate the effect of inductive and deductive approach in teaching grammar on EFL students' achievement in the Department of English Language and Literature at the Hashemite University. To achieve the aim of this study, the researchers used two-group pre- and post-test research. Due to the problems in teaching EFL in higher education in general and in the use of lecturing or deductive approach in teaching grammar in particular, the present study is seen an opportunity to explore the extent to which inductive grammar teaching is effective compared to deductive grammar teaching. Therefore, this study can help EFL instructors and researchers gain insight into the approach which suits the students' level of achievement.

\subsection{The Setting and Participants of the Study}

This study was carried out in the Department of English Language and Literature at the Hashemite University in Jordan. 105 EFL undergraduate students, enrolled in section 1 and section 2 in Grammar 2, participated in the study. The students, regarded as the experimental group, comprised 55 students in the first section, whereas the second section comprised 50 students. 76 of these students are females and 29 are males. 66 of them are first-year students and 39 are second-year ones. In addition, 70 students graduated from public schools and 35 from private ones. The experimental group was taught by using the inductive approach and the controlled one by the current or deductive approach. 


\subsection{The Material and Instrument of the Study}

The teaching material employed to examine the impact of these two approaches upon teaching grammar was chosen from the book adopted by the department, entitled Understanding and Using English Grammar: Fourth Edition. The grammatical issues taught by using inductive and deductive approach were: subject-verb agreement, noun forms, and pronouns.

The main instrument used to achieve the aims of the study was a pre-post-test developed by the researchers. This test included 25 sentences for the students to correct the underlined words or phrases (see the test below). In order to ensure the validity of the test, it was handed to three English language instructors, requesting them to suggest any necessary modifications or changes. As soon as the researchers received the copies of the test, they modified the original copy according to the instructors' comments. To establish the reliability of the test, the researchers used the test-retest technique. Then, they conducted a pilot study by giving the test to 20 students registered in section 3 . Three weeks later, the pilot group received the same test. By using Pearson's formula, the researchers calculated the reliability coefficient of the test, finding it to be 0.87 .

\subsection{Data Collection and Analysis}

The researchers themselves distributed both the pre- and post-tests to the target students. Then they collected and marked the test by pair-work. They used the pre-test to make sure if the experimental and controlled groups were equivalent. The researchers handed the post-test to the students after they were taught nine lessons on each approach. They used particular statistical techniques in the data analysis; they are the means, standard deviations, and the t-test. The researchers tried to find out if there were any statistical significant differences between the means of students' scores in the pre-and post-tests.

\section{The achievement test developed for the purpose of the preset study:}

\section{Achievement Test}

\section{Grammar 2}

\begin{tabular}{|c|c|c|c|c|}
\hline \multicolumn{5}{|c|}{ The school graduated from (Public or Private?)............................ } \\
\hline 1. & 6. & 11. & 16. & 21. \\
\hline 2. & 7. & 12. & 17. & 22. \\
\hline 3. & 8. & 13. & 18. & 23. \\
\hline 4. & 9. & 14. & 19. & 24. \\
\hline 5. & 10. & 15. & 20. & 25 \\
\hline
\end{tabular}

Each of the following sentences has four underlined words or phrases. The four underlined parts of the sentences are marked A, B, C, and D. Identify the one underlined word or phrase that must be changed in order for the sentence to be correct.

1. Almost every professor and student at the university approve of the choice of Dr. Helen as the new chair.
A
B
$\mathrm{C}$
$\mathrm{D}$

2. Some people say that having the responsibility for taking care of pets are good for young people.

A

B

$\mathrm{D}$

3. Getting to know students from all over the world are one of the best parts of my job. A B

4. Two-thirds of the students in the class is interested in reading translated English novels.

$$
\text { A }
$$

B

$\mathrm{C}$

$\mathrm{D}$

5. The number of students at HU are approximately twenty-eight thousand. This is relatively high.

6. A

B

$\mathrm{C}$

$\mathrm{D}$

7. Why was some of the students came late? Nobody knows.
A
B
$\mathrm{C}$
$\mathrm{D}$ 
8. Why are there a shortage of available apartments for rent in this city at present?
A
B
$\mathrm{C}$
D

9. He refused to pay twenty dollars. He thinks that 20 dollars are an unreasonable price for a card.
A B
C
D

10. The young is usually ignored by the officials thinking that they have no opinions.
$\mathrm{A}$
B
C
D

11. Diabetes are a disease that occurs when a person's blood sugar is too high.
A
$\mathrm{B}$
$\mathrm{C}$
D

12. Some people say that Portuguese are somewhat similar to $\underline{\text { Spanish. }}$
A
B
C
D

13. Thunder and lightning are phenomenon of nature in winter.
A
B C
$\mathrm{D}$

14. People get most of their news about the world through the mass medium.
A
B
C
D

15. Studying a foreign language usually motivate students to learn about the culture of the country.
$\mathrm{A}$
B
C
$\mathrm{D}$

16. Sally cannot study at home. She has a two-years-old brother who drives her nuts.
A
B
C
D

17. I could not grade all the students' papers. It is a ninety-eight-students class.
A
B
$\mathrm{C}$
$\mathrm{D}$

18. Nancy likes to wear jewelries. People say she has $20 \underline{\text { bracelets, }}, 40$ rings and 10 necklaces.
A
B
C
D

19. Being a parent has a lot of happiness, and responsibility at the same time.
A
B
$\mathrm{C}$
$\mathrm{D}$

20. The street is full of cars, trucks, and buses. It is full of traffics.
A
B
C
D

21. I don't like a lot of sugar in my tea. I add a little sugar to my tea.
A B
$\mathrm{C}$
D

22. Do you have a few minutes? I would like to ask you few questions.
A B
C D

23. Little advice from friends and family won't harm any person.
A B
$\mathrm{C}$
D

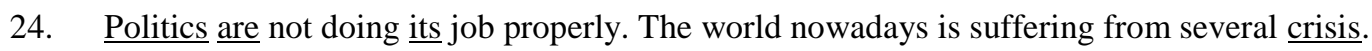
A B
C
$\mathrm{D}$

25. I don't like a lot of sugar in my tea. I add $\underline{\text { a little }}$ sugar to my tea.
A B
C
$\mathrm{D}$

26. Katherine needed some legal advice for her business, so she contacted two attorneys.
A
B
C
$\mathrm{D}$

\section{Results}

Before implementing the experiment, the researchers administrated the achievement test to the experimental and controlled groups to know the actual level of students. They used the means, standard deviations and the t-test to find out any significant differences between both groups in the pre-test, as shown in the table below: 
Table 1. Means, Standard Deviations and T-test results of the experimental and controlled groups on the pre-test

\begin{tabular}{cccccccc}
\hline & Group & $\mathrm{N}$ & Mean & Std. Deviation & $\mathrm{t}$ & $\mathrm{df}$ & Sig. (2-tailed) \\
\hline \multirow{3}{*}{ Pre-test } & Experimental & 55 & 12.45 & 2.456 & .277 & 103 & .783 \\
& Controlled & 50 & 12.32 & 2.527 & & & \\
\hline
\end{tabular}

*Significance at 0.05

Table 1 reveals that the means of students' scores for both groups are almost equivalent in the pre-test. That is, the difference between the scores of both groups on the test is not statistically significant. This indicates that the two groups are equal linguistically, before starting the experiment.

\subsection{Results Related to the First Research Question}

In order to answer the first research question "Are there are any statistical significant differences $(\alpha=0.05)$ between the means of students' achievement in grammar according to teaching approach (inductive and deductive)?", means of students' scores, standard deviations, and the 2-tailed significance were used as shown in the table below.

Table 2. Means, Standard Deviations and T-test results of the experimental and controlled groups on the post-test

\begin{tabular}{cccccccc}
\hline & Group & $\mathrm{N}$ & Mean & Std. Deviation & $\mathrm{t}$ & $\mathrm{df}$ & Sig. (2-tailed) \\
\hline \multirow{3}{*}{ Post-test } & Experimental & 55 & 16.25 & 2.682 & 2.577 & 103 & .011 \\
& & & & & & & \\
& Controlled & 50 & 14.82 & 3.022 & & & \\
\hline
\end{tabular}

Table 2 shows statistical significant differences at $(\alpha=0.05)$ between the means of students' scores in the two groups on the post-test, in favor of the experimental group. This indicates that the students taught through inductive approach in teaching grammar achieve better than those taught through the deductive one.

\subsection{Results Related to the Second Research Question}

In order to answer the second research question "Are there any statistical significant differences $(\alpha=0.05)$ between the means of students' achievement in grammar according to study-year (first and second year)?", the researchers used the means of students' achievement scores, standard deviations, and the 2-tailed significance as presented in the table below:

Table 3. Means, Standard Deviations and T-test results of the experimental and controlled groups according to study-year

\begin{tabular}{cccccccc}
\hline \multirow{2}{*}{ Experimental } & Year & $\mathrm{N}$ & Mean & Std. Deviation & $\mathrm{t}$ & $\mathrm{df}$ & Sig. (2-tailed) \\
& Year1 & 34 & 16.03 & 2.713 & -.789 & 53 & .433 \\
& Year2 & 21 & 16.62 & 2.655 & & & \\
\multirow{3}{*}{ Controlled } & Year1 & 32 & 14.91 & 2.810 & .199 & .267 & 48 \\
& Year2 & 18 & 14.67 & 3.447 & & & \\
\multirow{3}{*}{ Both } & Year1 & 66 & 15.48 & 2.797 & -.393 & 103 & .695 \\
& Year2 & 39 & 15.72 & 3.162 & & & \\
\hline
\end{tabular}

Table 3 shows no statistically significant differences at $(\alpha=0.05)$ between the means of first- and second-year students' scores in each of the experimental and controlled groups and in both groups together. This indicates that study-year does not have an impact on students' achievement in grammar in the post-test.

\subsection{Results Related to the Third Research Question}

To answer the third question "Are there any statistical significant differences $(\alpha=0.05)$ between the means of students' achievement in grammar according to the type of school they graduated from?", the researchers used the means, standard deviations, and the 2-tailed significance as illustrated in the table below: 
Table 4. Means, Standard Deviations and T-test results of the experimental and controlled groups according to the type of school they graduated from

\begin{tabular}{cccccccc}
\hline \multirow{2}{*}{ Experimental } & School & $\mathrm{N}$ & Mean & Std. Deviation & $\mathrm{t}$ & $\mathrm{df}$ & Sig. (2-tailed) \\
& Public & 34 & 16.24 & 2.786 & -.067 & 53 & .947 \\
& Private & 21 & 16.29 & 2.572 & & & \\
Controlled & Public & 36 & 14.94 & 2.927 & .463 & 48 & .645 \\
& Private & 14 & 14.50 & 3.345 & & & \\
\multirow{2}{*}{ Both } & Public & 70 & 15.57 & 2.912 & .000 & 103 & 1.000 \\
& Private & 35 & 15.57 & 2.993 & & & \\
\hline
\end{tabular}

Table 4 shows no statistically significant differences at $(\alpha=0.05)$ between the means of public- and private-school students' scores in each of the experimental and controlled groups and in both groups together. This reveals that students' achievement in the post-test with respect to grammar is relatively the same regardless of the type of school they graduated from.

\subsection{Results Related to the Fourth Research Question}

For answering the fourth research question "Are there any statistical significant differences $(\alpha=0.05)$ between the means of students' achievement in grammar according to gender (males and females)?", the researchers used the means, standard deviations, and the 2-tailed significance as shown in the table below.

Table 5. Means, Standard Deviations and T-test results of the experimental and controlled groups according to gender

\begin{tabular}{cccccccc}
\hline & Gender & $\mathrm{N}$ & Mean & Std. Deviation & $\mathrm{t}$ & $\mathrm{df}$ & Sig. (2-tailed) \\
\hline \multirow{2}{*}{ Experimental } & Male & 13 & 16.27 & 3.058 & .020 & 53 & .984 \\
& Female & 42 & 16.25 & 2.570 & & & \\
\multirow{3}{*}{ Controlled } & Male & 16 & 15.57 & 2.976 & 1.516 & 48 & .136 \\
\multirow{3}{*}{ Both } & Female & 34 & 14.28 & 2.987 & & & \\
& Male & 29 & 15.86 & 2.987 & .731 & 103 & .466 \\
& Female & 76 & 15.42 & 2.902 & & & \\
\hline
\end{tabular}

Table 5 shows no statistically significant differences at $(\alpha=0.05)$ between the means of males' and females' scores in each of the experimental and controlled groups and in both groups together. This means that students' achievement in the post-test with regard to grammar are relatively the same whether they are males or females.

\section{Discussion}

This current study aimed at exploring the effect of inductive and deductive approach on EFL undergraduates' achievement in grammar at the Hashemite University. In order to achieve this aim, the study attempted to answer four research questions through the results presented above. However, this section will discuss the results of each question.

Regarding the first research question about whether there are any significant differences between the means of students' achievement in grammar according to teaching approach (i.e., deductive and inductive), the results showed significant differences, in favor of inductive approach. This indicates that presenting examples that clarify a specific rule and expecting students to notice the way in which the rule work from these examples had a positive impact upon students' achievement. The reason lies in the fact that this approach allowed for easier retention of the rules than if the students were given an explanation that was disconnected from examples of the rule (Macfadyen, 2015; Donalo, Boyerlein \& Fiero, 2017; \& International Teacher Training Organization, 2019). However, this result agrees with the one found by (Gorat \& Prijambodo, 2013; Eriksson, 2014; Alzu'bi, 2015; Kaur \& Niwas, 2016; \& Benitez-Correa, Gonzalez-Torres; Ochoa-Gueva \& Vargas-Saritama, 2019) indicating that the inductive teaching approach was more effective in teaching grammar than the deductive teaching approach. On the other hand, the result does not agree with the findings of many other researchers. Some of them found that the deductive approach was more effective than the inductive in students' achievement in grammar (Mohammad \& Jaber, 2008; Sik, 2015; \& Negahdaripour \& Amirghassemi, 2016) and others claimed no significant differences between their achievement (Mahjoob, 2015; 
Emre, 2015; Hejvani \& Farahani, 2018; \& Ahmedzai, Katawazai \& SC, 2019).

Concerning the second research question related to whether there are any significant differences between the means of students' achievement in grammar according to study-year, results revealed no significant differences between the means of first- and second-year students' scores in each group and in both of them together. This indicates that study-year did not have an impact on students' achievement in grammar, regardless whether the approach employed was deductive or inductive. It was expected from second-year students to achieve better in grammar than first-year ones. The reason lies in the fact that they were exposed to more EFL courses, which might have enriched their linguistic and paralinguistic repertoire. Moreover, as long as language learners are exposed to tasks, they will be provided by ample opportunities to hear, see, use and manipulate language in contextualized, purposeful ways (Snow, 2019).

With respect to the third research question about any significant differences in the means of students' achievement according to the type of school they graduated from, the results showed no significant differences between the means of public- and private-sector students' scores in each of the experimental and controlled groups and in both together. This indicates that school the sector did not have a significant impact on students' achievement. It was anticipated that the students who graduated from the private sector would achieve better since they were exposed to more up-todate EFL curricula, to more English, and to more contemporary methods of teaching. This exposition might have helped these students go deeper into their specialization and achieve better results.

In terms of the fourth research question about any significant differences in the means of students' achievement according to gender, the results revealed no significant differences between the means of male and female students' scores in each of the experimental and controlled groups and in both of them together. This means that the students' achievement in grammar are relatively the same whether they are males or females. It was expected that the mean of females' scores would be higher than that of males. This could be attributed to the assumption that females have a more positive attitude towards learning a foreign language and do better than males in this regard. This is in consistent with Ellis's argument (1994) that women usually have a more positive attitude towards learning a second language, which has a greater impact on their way of learning and their performance in the language.

\section{Conclusion}

The results of the present study were limited to the setting and the tested participants. However, conducting research studies on English as an international language and at the university level is of paramount importance nowadays. The reason lies in the fact that the target subjects are regarded as an important axis around which everything revolves in the teaching-learning context. In addition, the variety of teaching methods in general and the adoption of contemporary ones in particular have become a necessity at the university level. Therefore, students' active performance or role and its relation to their achievement should be taken into consideration. Insisting on this orientation may keep us away from the lecturing method or from the deductive approach to teaching.

This study may be considered as an attempt to shed light on the impact of using the inductive and deductive approach upon the achievement of a sample of EFL undergraduate students with regard to grammar. Therefore, TEFL researchers are highly requested to conduct other studies on non-native speakers of English in higher education, the purpose of which is to determine the approach that best suits the students' level of achievement. This might help university EFL instructors employ appropriate methods of teaching in the classroom. This might also help English language departments develop in-service training courses for instructors to vary their methods of teaching.

\section{Acknowledgement}

We like to thank Prof. Jebreen Atyah and Miss Hanan Rjoub for preparing the lecturing wholes to carry out this study. We also like to thank Dr. Kefah Alomari for proof reading the study.

\section{References}

Ahmedzai, S., Katawazai, R., \& SC, S. (2019). The Use of Deductive and Inductive Approaches in Teaching Grammar for Afghan University Students of English and Literature Studies. International Journal of $\begin{array}{lllll}\text { Engineering and Advanced } & \text { Technology }\end{array}$ https://doi.org/10.35940/ijeat.E1175.0585C19

Alzu'bi, M.A. (2015). Effectiveness of Inductive and Deductive Methods in Teaching Grammar. Advances in Language and Literary Studies, 6(2), 187-191. https://doi.org/10.7575/aiac.alls 
Ana, K.T., \& Ratminingsih, N.M. (2012). Teaching English Tenses to EFL Learners: Deductive or Inductive? International Journal for Cross-Disciplinary Subjects in Education (IJCDSE), 2(2), 998-1004. https://doi.org/10.20533/ijcdse.2042.6364.2012.0142

Azar, B., \& Hagen, S. (2009). Understanding and Using English Grammar, Fourth Edition. Pearson Education, 10 Bank Street, White Plains, NY 10606.

Benitez-Correa, C., Gonzalez-Torres, P., Ochoa-Cueva, C., \& Vargas-Saritama, A. (2019). A Comparison between Deductive and Inductive Approaches for Teaching EFL Grammar to High School Students. International Journal of Instruction, 12(1e), 1308-1470. https://doi.org/10.29333/iji.2019.12115a

Bilash, O. (2009). Inductive and Deductive Instruction. Saskatchewan Education: Making Instructional Choices. sites.educ,ualberta.ca.

Decision tree. (2012). Differences between Inductive and Deductive Language Teaching. Differencebetween.net.

Donalo, L., Beyerlein, N., \& Fiero, S. (2017). Different Approaches to Teaching Grammar. TEFL Tales: TEFL Teacher Stories, ESL Tips and Interviews with TEFL Employers. Retrieved from: http://www.teflexpress.co.uk/blog

Ellis, R. (1994). The Study of Second Language Acquisition. Press, First Edition, Oxford, Oxford University Press Press.

Emre, D. (2015). The Effects of Inductive and Deductive Teaching and Learning on Written Output. Retrieved from: http:thesis.bilkent.edu.tr

Eriksson, L. (2014). The Effectiveness of Modified Inductive Versus Deductive Teaching: A case Study on Word Order amongst a Group of English as a Foreign Language Learners. Examensarbete for Kandidatexamen, $15 \mathrm{hp,}$ Engelska. http://www.tef/certificatecourses.com/tefl-articles/tesol-inductive-deductive-approaches.php

Gorat, L., \& Prijambodo, L. (2013). The Effect of Using Deductive Approach and Inductive Approach in Teaching English to Students on their Conditional Sentence Mastery. Magister Scientiae, 33, 78-92. Retrieved from: http://media.neliti.com

Hejvani, F., \& Farahani, M. (2018). An Investigation into Inductive and Deductive Methods in Teaching Grammar to German EFL Learners: A Comparative Study. Global Journal of Foreign Language Teaching, 8(2), 76-91. Retrieved from: http://www.giflt.eu. https://doi.org/10.18844/gjflt.v8i2.3202

International Teacher Training Organization. (2019). Inductive and Deductive Approach in TESOL. Retrieved from: http://www.Tefl.com

Kaur, S, \& Niwas, R. (2016). Effectiveness of Deductive and Inductive Methods in Teaching English Grammar at Elementary Level. International Journal of Advanced Research, 4(7), 1241-1247. https://doi.org/10.21474/IJAR01

Macfadyen, S. (2015). Different Methods of Teaching Grammar. Retrieved from: http://www.Inklyo.com

Mahjoob, E. (2105). A Comparison of the Effectiveness of Inductive vs. Deductive Instruction of Grammar to EFL Students. Journal of Language, Linguistics and Literature, 1(5), 164-169. Retrieved from: http://www.creativecommons.org/licenses/by-nc/4.0/

Mohammed, A., \& Jaber, H. (2008). The Effect of Deductive and Inductive Approaches of Teaching on Jordanian University Students' Use of the Active and Passive Voice in English. College Student Journal, 42(2), 1-13 pdfs.semanicscholar.org/6b48/

Negahdaripour, S., \& Amirghassemi, A. (2016). The Effect of Deductive vs. Inductive Grammar Instruction on Iranian EFL Learners' Spoken Accuracy. International Journal of Applied Linguistics \& English Literature, 5(1), 8-17. https://doi.org/10.7575/aiac.ijalel.v.5n.1p.8

Sik, K. (2015). Tradition or Modernism in Grammar Teaching: Deductive vs. Inductive Approaches. Procedia Social and Behavioral Sciences, 197, 2141 - 2144. Retrieved from: http://www.sciencedirect.com. https://doi.org/10.1016/j.sbspro.2015.07.340

Snow, C. (2019). Getting to the Roush Ground of Language and Literacy Learning through the Language Experience Approach. Theliteracybug.com/using-the-language-experience-approach. 